\title{
Reward Management Strategies and Employee Satisfaction in the Colleges of Kathmandu Valley
}

\author{
Jitendra Prasad Upadhyay, Pitri Raj Adhikari
}

\begin{abstract}
Background: Educational institutions set up a reward management system with the hope that it makes the employees perform their activities to the satisfaction of all concerned stakeholders. However, there are many contradictions and complaints about the performance of employees in colleges, compelling the undertaking the studies.Objectives:This study aims to examine the impact of reward management strategies on employee satisfaction in colleges of Kathmandu valley.Methods: This paper uses a questionnaire survey method of 300 respondentsof different 30 colleges/campuses of Kathmandu valleyand descriptive statistics and multiple regression models are used to analyze the data.Results:The beta coefficients are positive and significant for promotion, compensation, recognition, learning opportunities, and career development opportunity with employee satisfaction which indicates these variables have a positive impact on employee satisfaction.Conclusion: It is found that reward management is positively related to employee satisfaction and it is a powerful motivational factor that leads to job satisfaction.Implications:College management including universities may focus on identifying better reward management strategies to motivate the employees to enhance better productivity.
\end{abstract}

Keywords: Promotion, Compensation, Recognition, Learning Opportunities, Career Development Opportunities

\section{INTRODUCTION}

Employee satisfaction, a major asset, is animportant factor to achieve strategic goalsby increasing productivity and performance level of employees in the modern competitive business world for an organization, therefore, it is a researchable issue for practitioners and academicians for the last few decades. Various research shows that there are different dimensions of employee satisfaction. Among them, reward management strategy is an important factor that affects employee satisfaction.Jiang, Xiao, and Xiao (2009) focused that rewards management strategies that are used to manage transformation in organizations. Management needs to receive the reward policies to enhance employee performance because inadequate reward policies have significant relation with employee performance (Danish et al., 2019). Effective reward management is not only concerned with pay and employee benefits but it is also equally concerned with non-financial rewards such as promotion, compensation, recognition, learning opportunity and training, job responsibility, and career development opportunity.

Manuscript received on March 31, 2021.

Revised Manuscript received on April13, 2021.

Manuscript published on October10, 2021.

* Correspondence Author

Jitendra Prasad Upadhyay*, Associate Professor, Nepal Commerce Campus, TribhuvanUniversity, Kathmandu, Nepal

Pitri Raj Adhikari, Lecturer, Shanker Dev Campus, TribhuvanUniversity, Kathmandu, Nepal

(c) The Authors. Published by Lattice Science Publication (LSP). This is an open access article under the CC BY-NC-ND license (http://creativecommons.org/licenses/by-nc-nd/4.0/)
There is a positive relationship between promotion and employee performance and satisfaction (Schuler \& Jackson, 2005). Similarly, Tessema and Soeters (2006) argued that when employees are provided fair promotion in their organization for their better performance, the level of satisfaction eventually rises. Besides financial rewards, the employees also expect non-financial rewards i. e. job recognition, decision making, and appreciation from the organization which instrumental in improving the morale of employees and enhance their satisfaction level (Haider, Aamir, Abdulhamid, \& Hashim,2015)

Compensation is one of the most influencing factors affecting employees' satisfaction that drives organizational productivity(Okpara, 2004). It includes both direct financial payments and indirect payments. Pay is direct financial payment and Tella and Ibinaiye (2020) observed that employees are highly motivated with regular pay. Recognition is an important component ofemployees' satisfaction so that they consider recognition as their feelings of value and appreciation. There is a statistically significant relationship between employee satisfaction and recognition (Ali \&Ahemed, 2009)and recognition with job quality (Freedman, 1978). It is among the function of managers to motivate the employees successfully and influence their behaviour to achieve greater organizational efficiency (Galletta, 2011). Rewards and recognition play an imperative role in motivating employees and improving performance (Chepkwony\&Oloko, 2014).Similarly, Arokiasamy, Tat, and Abdullah (2013) argued that the commitment of all employees is based on rewards and recognition; there is a significant association exists between pay, promotion, and fringe benefits on job satisfaction among academic staff. Skilled manpower is essential to increase productivity and to reduce wastage and for this training and development (learning opportunity) helps to expand and polish the abilities and skills of employees which helps them to cope with problems in an organization. Khan, Nawaz, Alleem, and Hamed (2012) stated that training helps employees to be more specific with their job and organization which increases employee job satisfaction and make them work better. There is a positive relationship between employee job satisfaction and training and development (Gilbert \& Ivancevich, 2000).

Career development opportunity also plays a significant role to satisfy the employees. Mee-Edoiyee (2015) stated organizations that empower management of career are more likely to enlarge employee's job satisfaction. There are a strong and positive relationship and influence of total reward on retention (Akhtar, Aamir, Khurshid, Abro, \& Hussain 2015).

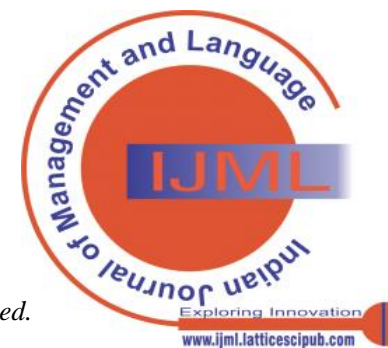


Likewise, Baniya (2004) concluded that the positive consequences of providing development opportunities to employees are improved performance, increased productivity, enhanced loyalty towards the organization, and increased motivation among employees. However, the negative consequences are demand for increment in salary, additional incentives and facilities, promotion, and demonstration of overconfidence in work, and the tendency to leave the job.Emuron (2020) concluded a positive and significant relationship between reward management system (RMS) and cost of living (COL), a significant relationship between the cost of living and performance of academic staffs, and a moderate and significant relationship between RMS and performance.

According to Torlak and Kuzey (2019), contingent rewards had no significant relation with employee job satisfaction and weak positive significant association with employee job performance. Rewards dimensions have a significant and positive impact on employee motivation (Muhammed, 2016; Rashmi \& Umesh, 2017;Aktar\& Muhammed, 2013; Gyawali, 2016; Thapa, 2016). Similarly, failure in designing an appropriate reward system has continued to hurt employees' job satisfaction and the overall effectiveness of many organizations (Neo, Gerhar, \& Wright 2006). Therefore, the above discussions show that studies dealing with reward management strategies and employee satisfaction are of greater significance. Moreover, research has been done concerning these issues in the western context; however, there are very little research has been done in the Nepalese context. Hence, this paper attempts to examine the impact of reward management strategies on employee satisfaction in colleges of Kathmandu valley. The remainder part of this paper is organized as follows: research hypotheses, methods, results and discussions, conclusion and references respectively.

\section{OBJECTIVES OF THE STUDY}

The main objective of the study is to analyze the impact of reward management strategies on employee satisfaction in colleges of Kathmandu valley.

The other specific objectives are:

a. To examine the relation between promotion with employee satisfaction

b. To examine the relation between compensation with employee satisfaction

c. To examine the relation between recognition with employee satisfaction

d. To examine the relation between learning opportunities with employee satisfaction

\section{RESEARCH HYPOTHESES}

This paper has set the following alternative hypotheses:

$H_{1}$ : There is a positive relationship between promotion and employee satisfaction.

$\mathrm{H}_{2}$ : There is a positive relationship between compensation and employee satisfaction.

$\mathrm{H}_{3}$ : There is a positive relationship between recognition and employee satisfaction.

$\mathrm{H}_{4}$ : There is a positive relationship between learning opportunities and employee satisfaction.
$H_{5}$ : There is a positive relationship between career development opportunities and employee satisfaction.

\section{LIMITATIONS OF THE STUDY}

The following are the limitations of the study.

1. This research has examine the relationship between reward management and the employee satisfaction only.

2. This research has examine the four components of reward management only i.e. promotion, compensation, recognition and learning opportunity.

3. Only selected statistical tools \& techniques have been used as demanded by the objectives of the study, e.g. averages, correlation and regression for the purpose of the research.

4. Only 300 respondents from 30 colleges from Kathmandu Valley have been selected for the studies.

5. Only employee satisfaction has been analyzed through reward management

\section{METHODOLGY USED}

Descriptive research design has been used to search for adequate information to analyze the relationshipbetweenreward management strategies towards employee satisfaction. Similarly, causal-comparative research design has also adapted to establish the cause and effect relationship of promotion, recognition, compensation, learning opportunities, and career development opportunities with employee satisfaction. Out of total employees from total colleges of Kathmandu Valley only 300 employees from 30 colleges have taken as sample. Sampling was done using convenience and judgemental sampling techniques.

Data are collected through the structured questionnaire which contains the respondent related information, and fivepoint Likert scale i.e.1 represent strongly agree to 5 represent strongly disagree has been used for the analysis. The relationship between the dependent and independent variables are analyzed in multi-step regression analysis. The model is:

$E P=\alpha+\beta_{1} P+\beta_{2} C+\beta_{3} R+\beta_{4} L O+\beta_{5} C D O+\varepsilon$

Where, $\mathrm{P}=$ Promotion, $\mathrm{C}=$ Compensation, $\mathrm{R}=$ Recognition, $\mathrm{LO}=$ Learning opportunities, $\mathrm{CDO}=$ Career development opportunities, $\mathcal{E}=$ error term, $\alpha=$ constant term $\beta_{1}, \beta_{2}, \beta_{3}, \beta_{4}$, $\beta_{5}$ arethe beta coefficient of the explanatory variables to be estimated.

\section{RESULTS AND DISCUSSIONS}

\section{Descriptive analysis}

The mean value of promotion ranges from a minimum value of 2.22 to a maximum value of 2.51 and the weighted average is 2.39 that states promotion is better to reward management strategies for employee satisfaction in colleges. 
Similarly, the mean value of compensation ranges from a minimum value of 1.73 to a maximum value of 2.49 and,the weighted average is 2.14 that indicates compensation isa better reward management strategy for employee satisfaction. Likewise, the mean value of recognition ranges from a minimum value of 2.21 to a maximum value of 2.51 and the weighted average is 2.31 which reveals recognition is better to reward management strategy for employee satisfaction. Additionally, the mean value of learning opportunities ranges from a minimum value of 1.79 to a maximum value of 2.42 and the weighted average is 2.20 which means learning opportunities are better reward management strategies for employee satisfaction.

Similarly, the mean value of career development opportunities ranges from a minimum value of 1.72 to a maximum value of 2.52 and the weighted average is 2.19 that exhibits career development opportunities are better reward management strategies for employee

\begin{tabular}{|c|c|c|c|c|c|c|c|c|}
\hline Variables & Mean & SD & $\mathrm{P}$ & $\mathrm{C}$ & $\mathrm{R}$ & $\mathrm{LO}$ & CDO & ES \\
\hline $\mathrm{P}$ & 2.31 & 0.698 & 1 & & & & & \\
\hline C & 2.14 & 0.671 & $0.501^{* *}$ & 1 & & & & \\
\hline $\mathrm{R}$ & 2.31 & 0.587 & $0.512^{* *}$ & $0.516^{* *}$ & 1 & & & \\
\hline LO & 2.20 & 0.599 & $0.556^{* *}$ & $0.472^{* *}$ & $0.521^{* *}$ & 1 & & \\
\hline CDO & 2.19 & 0.698 & $0.497^{* *}$ & $0.511^{* *}$ & $0.502^{* *}$ & $0.527^{* *}$ & 1 & \\
\hline ES & 2.38 & 0.662 & $0.531^{* *}$ & $0.487^{* *}$ & $0.587^{* *}$ & $0.528^{* *}$ & $0.538^{* *}$ & 1 \\
\hline
\end{tabular}

satisfaction.Moreover, the mean value of employee satisfaction ranges from a minimum value of 1.87 to a maximum value of 2.65 and the weighted average is 2.38 that indicates employees are satisfied.

\section{Correlation analysis}

Table 1

\section{Correlation Matrix}

This table presents Kendal's tau correlation coefficient between the dependent variable (employee satisfaction) with the independent variables(promotion, compensation, recognition, learning opportunities, career development opportunities). The correlation coefficients are based on 300 observations.

Notes: **sign indicates that correlation is significant at 1 percent level.

*sign indicates that correlation is significant at 5 percent levels.

The resultsreveal that all independent variables are positively correlated with employee satisfaction which means a higher level of promotion, higher would be the employee satisfaction; a higher level of compensation, higher would be employee satisfaction; more the employees are recognized for better performance, the higher would be employee satisfaction; increase in learning opportunities leads to increase in employee satisfaction; and more the employees are provided the career development opportunities, higher would be employee satisfaction.
Regression Results

The table presents regression results based on the model: $E P=\alpha+\beta_{1} P+\beta_{2} C+\beta_{3} R+\beta_{4} L O+\beta_{5} C D O+\varepsilon$ where, $P=$ Promotion, $C=$ Compensation, $R=$ Recognition, $L O=$ Learning opportunities, $C D O=$ Career development opportunities, $\mathcal{E}=$ error term, $\alpha=$ constant term $\beta_{1}, \beta_{2}, \beta_{3}, \beta_{4}, \beta_{5}$ arethe beta coefficient of the explanatory variables.

\section{Regression analysis}

Table 2

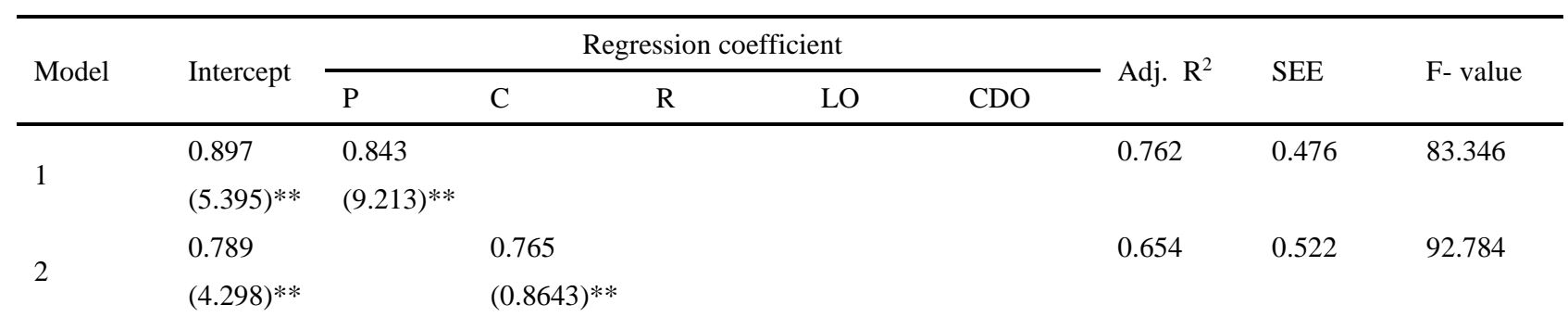




\begin{tabular}{|c|c|c|c|c|c|c|c|c|c|}
\hline & 0.565 & & & 0.865 & & & 0.708 & 0.487 & 123.639 \\
\hline \multirow[t]{2}{*}{3} & $(2.873)^{*}$ & & & $(11.276)^{* *}$ & & & & & \\
\hline & 0.98 & & & & 0.785 & & 0.602 & 0.871 & 66.983 \\
\hline \multirow[t]{2}{*}{4} & $(4.517)^{* *}$ & & & & $(8.234)^{* *}$ & & & & \\
\hline & 1.003 & & & & & 0.876 & 0.653 & 0.671 & 89.936 \\
\hline \multirow[t]{2}{*}{5} & $(5.915)^{* *}$ & & & & & $(9.498)^{* *}$ & & & \\
\hline & 0.539 & 0.564 & 0.614 & & & & 0.543 & 0.521 & 67.129 \\
\hline \multirow[t]{2}{*}{6} & $(2.713)^{*}$ & $(4.567)^{* *}$ & $(5.116)^{* *}$ & & & & & & \\
\hline & 0.245 & 0.218 & 0.345 & 0.521 & & & 0.632 & 0.543 & 55.234 \\
\hline \multirow[t]{2}{*}{7} & 1.136 & $(2.685)^{*}$ & $(2.781)^{*}$ & $(4.330)^{* *}$ & & & & & \\
\hline & 0.198 & 0.212 & 0.332 & 0.385 & 0.088 & & 0.675 & 0.511 & 41.382 \\
\hline \multirow[t]{2}{*}{8} & 1.156 & $(2.211)^{*}$ & $(2.618)^{*}$ & $(4.132)^{* *}$ & 0.985 & & & & \\
\hline & 0.316 & & 0.299 & 0.563 & 0.084 & 0.412 & 0.765 & 0.462 & 42.28 \\
\hline \multirow[t]{2}{*}{9} & 1.312 & & $(2.343)^{*}$ & $(3.867)^{* *}$ & 0.936 & $(2.534)^{*}$ & & & \\
\hline & 0.23 & 0.205 & 0.432 & 0.512 & 0.022 & 0.216 & 0.672 & 0.652 & 35.092 \\
\hline 10 & 1.214 & 1.776 & 1.876 & $(3.597)^{* *}$ & 0.311 & $(0.199) *$ & & & \\
\hline
\end{tabular}

i. $\quad$ Figures in parentheses are t-values.

ii. $\quad$ The asterisk signs (**) and (*) indicate that the results are significant at 1 percent and 5 percent level respectively.

Table 2 shows that the beta coefficients are positive and significant for promotion with employee satisfaction which indicates promotion has a positive impact on employee satisfaction and the result is similar to the result of Tessema and Soeters (2006). Similarly,the positive beta for compensation reveals that it has a positive impact on employee satisfaction and it is consistent with the findings of Kelly and Hoffman (1997). Likewise,a positive beta for recognition states that it has a positive impact on employee satisfaction and this finding consistent with the finding of Andrew (2004). Furthermore, the beta coefficients for learning opportunities are positive with employee satisfaction that means learning opportunities havea positive impact on employee satisfaction and this result is same as the findings of Gilbert and Ivancevich (2000).Additionally, the beta coefficients for career development opportunities are positive with employee satisfaction which indicates CDO hasa positive impact on employee satisfaction and it is similar to the findings of Appelbaum, Ayre, and Shapiro (2002).

\section{CONCLUSION}

Employee satisfaction is an important factor to achieve strategic goals by increasing productivity and performance level of employees in every organization and reward management strategy is an important tools for influening employee satisfaction.

It is observed that reward management is strongly related to employee satisfaction and it is a powerful motivational factor that leads to job satisfaction.It is found that promotion, compensation, recognition, learning opportunities, and career development opportunities have a positive impact on employee satisfaction in colleges of Kathmandu valley.

\section{IMPLICATIONS}

The following are the implications of the study: i. The future researcher should extend the other appropriate approaches for satisfying the employee.

ii. Large number of samples of employees should be taken so that the findings would be more authentic and reliable. iii. They are advised to include other stakeholders like faculties, students, employers and entrepreneurs' too.

iv. More sophisticated statistical \& mathematical models can be used to analyze and interpret data further.

\section{REFERENCES}

1. Akhtar, C. S., Aamir, A., Khurshid, M. A., Abro, M. M. Q., \& Hussain, J. (2015). Total reward and retention: A case study of higher education institutions in Pakistan. Procedia - Social and Behavioral Sciences, 210, 251-259.

2. Akhtar, U., \& Md, S. M. (2013). The impact of rewards on job satisfaction and employees' performance in Bangladesh: A comparative analysis between pharmaceutical and insurance industries. International Journal of Business and Management Invention,2(8), 01-08.

3. Ali, R., \& Ahmed, M. S. (2009). The impact of reward and recognition programs on employee's motivation and satisfaction: an empirical study. International Review of Business Research Papers, 5(4), 270-279.

4. Amah, E., Nwuche, C.,\&Chukwuigwe, N. (2013). Effective reward and incentive scheme for effective organizations. Research Journal of Finance and Accounting,4(3), 7379.

5. Arokiasamy, A.R.A.,Tat, H.H., \&Abdullah, A. G. K.(2013). The effects of the reward system and motivation on job satisfaction: Evidence from the education industry in Malaysia. World Applied Sciences Journal, 24(12), 1597-1604.

6. Baniya, L. B. (2004). Human resource development practice in Nepalese business organization. A case study of manufacturing enterprises in Pokhara. Journal of Nepalese Business Studies, 1(1), 58-68.

7. Chepkwony, C. C.,\&Oloko, M. (2014). The relationship between rewards systems and job satisfaction:A case study at teachers' service commission-Kenya. European Journal of Business and Management, 3(1), 59-70.

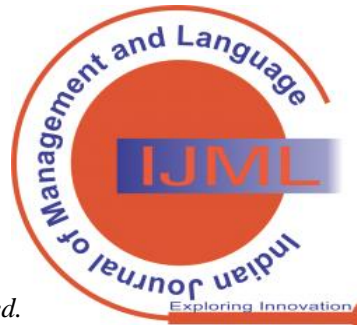


8. Danish, R. Q., Qaseem, S., Mehmood, T., Ali, Q. M., Ali, H. F., \& Shahid, R. (2019). Work-related stressors and teachers' performance: Evidence from college teachers working in Punjab. European Scientific Journal, 15(4), 158-173.

9. Emuron, L. (2020). Progressive reward management system model for university governance. International Journal of Advanced Research and Publications, 4(4), 129-138.

10. Freedman, M. S. (1978). Some determinants of compensation decisions.Academy of Management,21, 397-409.

11. Galletta, M., Portoghese,I.,\&Battistelli, A.(2011). Intrinsic motivation, job autonomy, and turnover intention in the Italian healthcare: The mediating role of affective commitment. Journal of Management Research, 3(2), 1-15.

12. Gilbert, J. A., \& Ivancevich, J. M. (2000). Valuing diversity: A tale of two organizations. The Academy of Management Executive, 14(1), 93-105.

13. Gyawali, A. (2016). Impact of reward on employee motivation of Nepalese commercial banks. Nepalese Journal of Management, 3(3), 163-175.

14. Haider, M., Aamir, A., Abdulhamid, A., \& Hashim, M. (2015). A literature analysis of the importance of non-financial rewards for employees, job satisfaction. Abasyn Journal of Social Sciences, 8(2), 341- 351.

15. Jiang, Z., Xiao, Q., \& Xiao, L. (2009). Total rewards strategy: A human resources management strategy going with the trend of the times. International Journal of Business and Management, 4 (11), 177-184.

16. Khan, A. H., Nawaz, M. M., Aleem, M., \& Hamed, W. (2012). Impact of job satisfaction on employee performance: An empirical study of autonomous medical institutions of Pakistan. African Journal of Business Management, 6(7), 2697-2705.

17. Mee-Edoiye, M.E. (2015). The impact of the reward system on the productivity of construction employees. A study of selected construction projects in Port Harcourt. Journal of Public Economics, 6(7), 217-219.

18. Mohammed, R. A. (2016). Influence of intrinsic and extrinsic rewards on employee performance: The banking sector of Pakistan. Academic Research International Journal, 4(1), 1-29.

19. Okpara, J. O. (2004). The impact of salary differential on managerial job satisfaction: A study of the gender gap and its implications for management education and practice in a developing economy. Journal of Business in Developing Nations, 8(1), 65-91.

20. Rashmi, R., \& Umesh, M. (2017). Impact of rewards on employee performance. A case of Indian Oil Corporation. Journal of Business and Management, 16(2), 29-36.

21. Schuler, R.S., \& Jackson, S. E. (2005). Human Resource Management: Positioning for the $21^{\text {st }}$ Century.(6 $6^{\text {th }}$ Ed.). New York: West Publishing.

22. Torlak, N. G., \&Kuzey, C. (2019). Leadership, job satisfaction, and performance links in private education institutes of Pakistan. International Journal of Productivity and Performance Management, 68(2), 276-295.

23. Tella, A., \&Ibinaiye, O. A. (2020). Correlates of staffs motivation, satisfaction, and job performance of library staffs in selected Nigerian University libraries. International Information \& Library Review, 52(1), 32-49.

24. Tessema, M.,\&Soeters, J. (2006). Challenges and prospects of HRM in developing countries: Testing the HRM performance link in Eritrean civil service. International Journal of Human Resource Management. 17(1), 86-105

25. Thapa, N. (2016). Impact of training and motivation on employees' performance in Nepalese commercial banks. Nepalese Journal of Business, 3(4), 78-91.

\section{AUTHORS PROFILE}

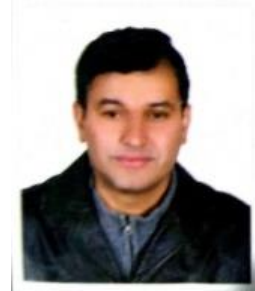

Mr.Pitri Raj Adhikari, is a Ph. D. scholar, and lecturer at Shanker Dev Campus, Tribhuvan University. He has written many research articles and textbooks in the management area. He has presented papers in national and international conferences and has participated in several workshops and seminars. He is a member of Finance Subject Committee at Shanker Dev Campus since 2008.

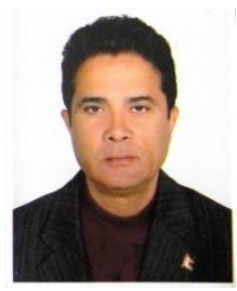

Jitendra Prasad Upadhyay, (MBA, MPhil and Ph. D.), Associate Professor at Tribhuvan University, Nepal, co-authored books in Accounting and Management and published more than five dozens articles in Nepalese and International Journals. He has been participating different workshops and seminars in Nepal and India. He is a Standing Committee Member of Account Subject Committee at Tribhuvan University. 